\title{
Extremus adstrictus from a dolomite wall in Poland: the first report outside Mallorca
}

\author{
Magdalena Owczarek-Kościelniak ${ }^{*}$
}

\author{
Article info \\ Received: 13 Oct. 2020 \\ Revision received: 8 Nov. 2020 \\ Accepted: 18 Nov. 2020 \\ Published: 29 Dec. 2020 \\ Associate Editor \\ Marcin Piątek
}

\begin{abstract}
Most species belonging to the Extremaceae family are rock-inhabiting fungi (RIF), which have a deteriorative potential towards colonized substrate. Extremus adstrictus originally isolated from limestone formations in Mallorca is reported from a dolomite wall in Poland. It is the first non-Spanish documented occurrence of this species. Identification of the strain is supported by morphological and molecular analyses. Sequences of uncharacterized fungal cultures and environmental data are analyzed in order to verify probable distribution of Extremus adstrictus.
\end{abstract}

Key words: Extremaceae, rock-inhabiting fungi, ITS, LSU, phylogeny

\section{Introduction}

Rock-inhabiting fungi (RIF) are a group of a poikilotolerant fungi (Gorbushina \& Krumbein 2000) with geographical distribution being nearly as wide as rock itself (Friedmann 1982; Staley et al. 1982; Ruibal et al. 2005, 2008; Selbmann et al. 2005, 2008, 2014; Sert et al. 2007; Onofri et al. 2014; Egidi et al. 2014; Su et al. 2015; Isola et al. 2016; Brewer \& Fierer 2018; Owczarek-Kościelniak et al. 2020; Sun et al. 2020). RIF, forced to withstand harsh environmental conditions, have developed a number of adaptations needed for survival. These small, slow growing fungi are able to reside under various climatic conditions, including ambient temperatures, high solar irradiation, osmotic stress, low water availability and limited nutrient source (Sterflinger \& Krumbein 1995; Selbmann et al. 2005; Dadachova \& Casadevall 2008; Onofri et al. 2012; Tesei et al. 2012; Isola et al. 2013; Zakharova et al. 2013).

The family Extremaceae, where most of the described species are RIF, was introduced in 2014 (Quaedvlieg et al. 2014) as a result of resolving a clade formerly known as Teratosphaeriaceae II. Currently, Extremaceae accommodates the following genera: Extremus, Petrophila, Saxophila, Staninwardia, Pseudoramichloridium, Vermiconidia (Wijayawardene et al. 2018), Castanedospora, Paradevriesia (Hongsanan et al. 2020; Wijayawardene et al. 2020) and Neohortaea (Delgado et al. 2018). All type species of these genera, except Staninwardia, are sequenced. Most of the species of the Extremaceae family were isolated from rock samples from sites located

Department of Mycology, W. Szafer Institute of Botany, Polish Academy of Sciences, Lubicz 46, 31-512 Kraków, Poland

* Corresponding author e-mail: m.owczarek@botany.pl in Mallorca and Antarctica. The genera Staninwardia, Pseudoramichloridium, Castanedospora and Neohortaea originate from plant, soil and lignite material.

The genus Staninwardia was first introduced with Staninwardia breviuscula from Eucalyptus leaves (Sutton 1971). The second Staninwardia species discovered, S. suttoni, was isolated from Eucalyptus robusta in Australia (Summerell et al. 2006) and remains the only sequenced representative of the genus. The genus Pseudoramichloridium was first introduced in 2009 (Cheewangkoon et al. 2009) when Pseudoramichloridium henryi was isolated from Corymbia henryi. Simultaneously, originally described in 2007 as Ramichloridium brasilianum, an isolate from forest soil, was recombined and introduced as a second representative of the Pseuchoramichloridium genus. The third species of the genus, Pseudoramichloridium xinjangense, was isolated from soil and described in 2017 (Jiang et al. 2017), but was not sequenced. The genus Castanedospora includes a single species, Castanedospora pachyanthicola, originating from dead leaves of Pachyanthus poiretii and Sabal palmetto in Cuba and the USA (Delgado et al. 2018). The genus Neohortaea accommodates a single species, Neohortaea acidophila, isolated from lignite (Hölker et al. 2004; Quaedvlieg et al. 2014).

The genera Petrophila and Saxophila are each represented by a single species - Petrophila incerta and Saxophila tyrrhenica, respectively, isolated from stone and a stone monument located in the Mediterranean (Egidi et al. 2014; Isola et al. 2016; Crous et al. 2019). Vermiconidia (Crous et al. 2019), originally published as a Vermiconia (Egidi et al. 2014) includes four species, Vermiconidia antarctica isolated only from Antarctica, 
V. calcicola found at various sites in Italy, $V$. flagrans reported from the Mediterranean and $V$. foris originating from Italian Alps. All described species and strains of Vermiconidia were isolated from stone substrates. Similarly, the two described species of the genus Extremus are a rock-inhabiting fungi with $E$. antarcticus isolated from McMurdo Valleys in Antarctica and E. adstrictus from limestone formations in Mallorca (Ruibal et al. 2005; Quaedvlieg et al. 2014; Crous et al. 2019).

The genus Paradevriesia was introduced by Crous et al. (2019) and originally transferred to a new family, Paradevriesiaceae. Paradevriesia is comprised of Paradevriesia compacta from rocks, P. americana from air and P. pseudoamericana from Malus domestica fruit (Crous et al. 2019). The family Paradevriesiaceae is now regarded as a synonym of Extremaceae (Hongsanan et al. 2020; Wijayawardene et al. 2020).

In this work, the strain isolation of Extremus adstrictus from a second location, a dolomitic wall in the center of Kraków, Poland, is reported. Morphological and molecular characteristics of this new specimen are provided.
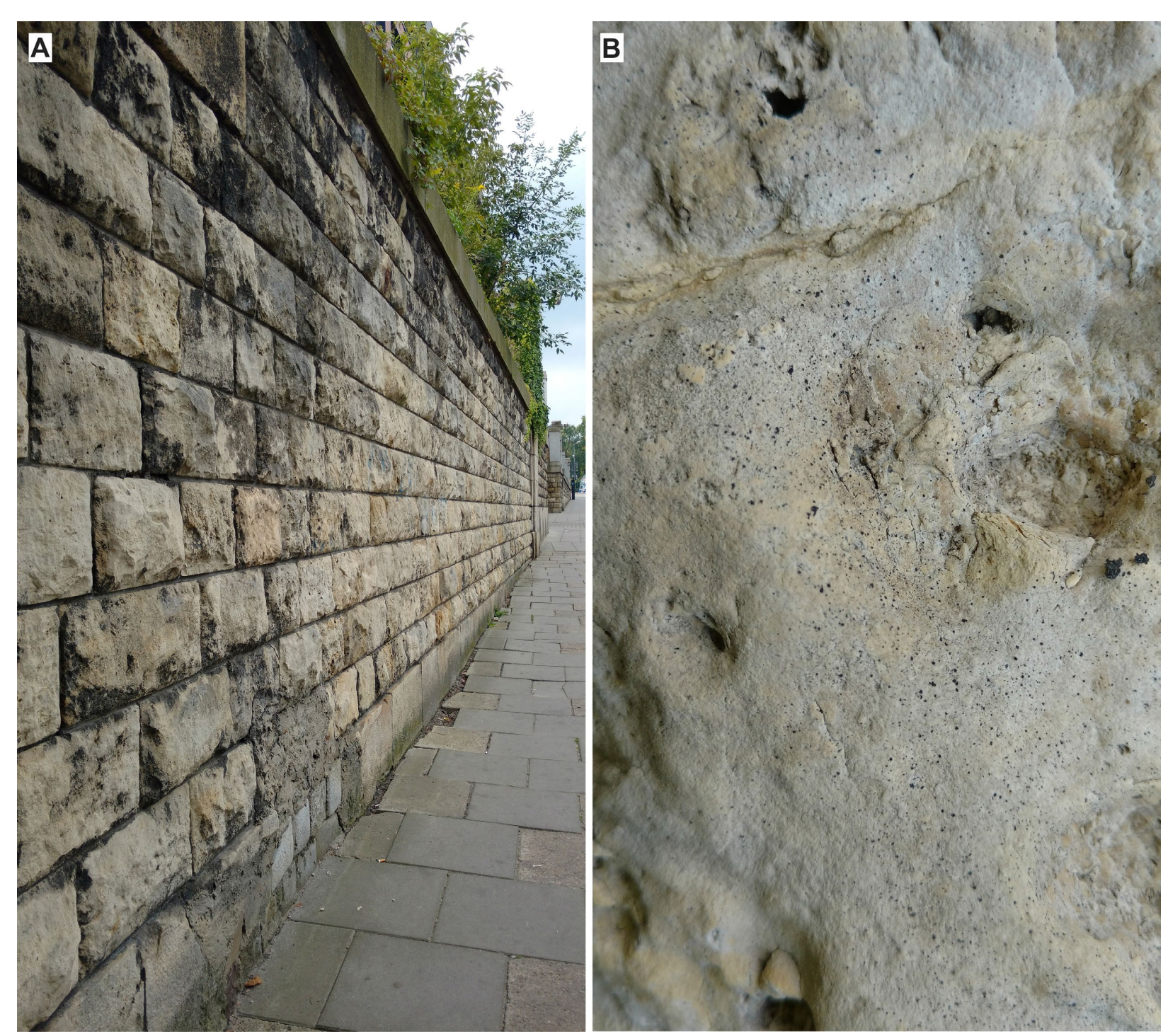

Figure 1. Sampling site. A - view of the dolomitic wall in Kraków; B - black fungi colonization at the surface and in pits of a dolomite slate.

\section{Materials and methods}

Located in southern Poland, the city of Kraków is the second largest city in the country. The climate of Kraków is moderately humid continental with cold winters and warm to hot summers (Grøntoft 2017). Small fragments of a dolomite retaining wall situated in the center of Kraków, Poland (Fig. 1) were sterilely collected in May 2018 and transferred to small tubes. In laboratory conditions, wall fragments were crushed in a mortar under sterile conditions and scattered on malt extract agar (MEA) medium as inoculum as described in Owczarek-Kościelniak et al. (2020). After 12 weeks of growth on MEA medium at $15^{\circ} \mathrm{C}$, colonies were used for morphological description and molecular analyses. The isolated strain was deposited in the culture collection of the Westerdijk Fungal Biodiversity Institute (CBS) and as a dried voucher specimen in fungal collection of the W. Szafer Institute of Botany, Polish Academy of Sciences, Kraków (KRAM F).

Culture characteristics were studied on MEA medium. Measurements and photographs of the colonies were taken using 6 month old cultures. Micromorphological

\footnotetext{
Figure 1. Sampling site. A - view of he domitic wall in Krakw; B - black fingi coloniztion the surface and pis of a dolomite slae.
} 
observations were made on 3 month old and 6 month old cultures. Slides were mounted with Shear's medium and observed with a Nikon Eclipse 80i light microscope at a magnification of $1000 \mathrm{X}$. The microscopic structures were measured and photographed using NIS-Elements BR 3.0 imaging software.

DNA extraction was performed following the Gerrits van den Ende and de Hoog (1999) protocol optimized by Owczarek-Kościelniak and Sterflinger (2018). The PCR reactions were performed in a $25 \mu \mathrm{l}$ volume containing
$1 \mathrm{X}$ buffer (with $\mathrm{MgCl}$ ), $200 \mu \mathrm{M}$ dNTP, 5 pmol forward and backward primers and $0.05 \mathrm{U}$ Taq polymerase (Sigma Aldrich). Primers selected for the reaction were ITS-1F (5'-CTT GGT CAT TTA GAG GAA GTA A-3') (Gardes $\&$ Bruns 1993) and ITS-4 (5'-TCC TCC GCT TAT TGA TAT GC-3') (White et al. 1990) for the ITS1-5.8S-ITS4 rDNA (ITS) region, and NL1 (5'-GCA TAT CAA TAA GCG GAG AA AAG-3') and NL4 (5'-GGT CCG TGT TTC AAG ACG G-3') (O'Donnell 1993) for the D1-D2 domains of the $28 \mathrm{~S}$ rDNA (LSU) gene. ITS amplification

Table 1. Fungal sequences used in phylogenetic reconstruction. Sequences generated in this study are shown in bold. T - type strain; ET - extype strain.

\begin{tabular}{|c|c|c|c|c|c|c|}
\hline \multirow{2}{*}{ Species } & \multirow{2}{*}{ Strain } & \multirow{2}{*}{ Source } & \multirow{2}{*}{ Country } & \multicolumn{3}{|c|}{ NCBI accession number } \\
\hline & & & & ITS & LSU & $R P B 2$ \\
\hline $\begin{array}{l}\text { Castanedospora } \\
\text { pachyanthicola }\end{array}$ & HKUCC 10835 & - & China & - & DQ408557 & - \\
\hline $\begin{array}{l}\text { Castanedospora } \\
\text { pachyanthicola }\end{array}$ & CBS $140347 \mathrm{~T}$ & Sabal palmetto & USA & MH036004 & MH036005 & - \\
\hline Cladosporium fusiforme & CBS 119414T & hypersaline water & Slovenia & NR_119608 & KJ564333 & - \\
\hline Cladosporium iridis & CBS 138.40ET & Iris sp. & Netherlands & NR_111271 & EU167591 & KT223022 \\
\hline Extremus adstrictus & CBS $118292=$ TRN96ET & rock sample & Spain & NR_144954 & KF310022 & KF310103 \\
\hline Extremus adstrictus & W3 & rock sample & Poland & MW206772 & MW206771 & - \\
\hline Extremus antarcticus & CCFEE 5312 & rock sample & Antarctica & KF309979 & KF310020 & KF310086 \\
\hline Extremus antarcticus & CBS $136104=$ CCFEE 5207 & rock sample & Antarctica & - & KF310021 & - \\
\hline Extremus antarcticus & CBS $136103 \mathrm{~T}=$ CCFEE 451 & rock sample & Antarctica & NR_138389 & NG_059204 & KF310085 \\
\hline Extremus sp. & CBS $119436=$ CCFEE 5177 & rock sample & Antarctica & - & KJ564326 & - \\
\hline Extremus sp. & CCFEE 5551 & - & - & - & KC315879 & - \\
\hline Extremus sp. & CBS $118300=$ TRN137 & rock sample & Spain & - & GU323973 & KF310098 \\
\hline Neohortaea acidophila & CBS 113389 & - & Germany & GU214636 & GU214428 & GU357768 \\
\hline Paradevriesia americana & CBS 117726ET & air sample & USA & NR_159866 & NG_059077 & - \\
\hline Paradevriesia compacta & CBS $118294=$ TRN111ET & rock sample & Spain & NR_144955 & NG_059089 & KF310095 \\
\hline $\begin{array}{l}\text { Paradevriesia } \\
\text { pseudoamericana }\end{array}$ & CPC 16174T & Malus domestica & Germany & GU570527 & GU570544 & - \\
\hline Petrophila incerta & CBS $118287=$ TRN77 & rock sample & Spain & AY559337 & GU323963 & KF310101 \\
\hline Petrophila incerta & CBS $118305=$ TRN62 & rock sample & Spain & AY559328 & GU323961 & KF310084 \\
\hline Petrophila incerta & CBS $118608=$ TRN139bET & rock sample & Spain & NR_144956 & KF310030 & KF310091 \\
\hline Polychaeton citri & CBS 116435 & Citrus aurantium & Iran & GU214649 & GU214469 & - \\
\hline $\begin{array}{l}\text { Pseudoramichloridium } \\
\text { brasilianum }\end{array}$ & CBS 283.92ET & forrest soil & Brazil & EU041797 & EU041854 & - \\
\hline $\begin{array}{l}\text { Pseudoramichloridium } \\
\text { henryi }\end{array}$ & CBS $124775=\mathrm{CPC} 13121 \mathrm{ET}$ & Corymbia henryi & Australia & NR_156571 & NG_057832 & KF902344 \\
\hline Saxophila tyrrhenica & TRN66 & rock sample & Spain & AY559330 & GU323962 & - \\
\hline Saxophila tyrrhenica & CBS 139725 = CCFEE 5935T & rock sample & Italy & NR_145013 & NG_059571 & - \\
\hline Staninwardia suttonii & CBS $120061=$ CPC 13055ET & Eucalyptus robusta & Australia & NR_137118 & NG_058023 & KF442591 \\
\hline $\begin{array}{l}\text { Toxicocladosporium } \\
\text { protearum }\end{array}$ & CBS $126499=\mathrm{CPC} 15254 \mathrm{ET}$ & Protea burchellii & South Africa & NR_152321 & HQ599587 & KJ564344 \\
\hline $\begin{array}{l}\text { Toxicocladosporium } \\
\text { irritans }\end{array}$ & CBS $128777=\mathrm{CPC} 18471 \mathrm{ET}$ & $\begin{array}{l}\text { Phaenocoma } \\
\text { prolifera }\end{array}$ & South Africa & MH865133 & JF499868 & KJ564345 \\
\hline $\begin{array}{l}\text { Toxicocladosporium } \\
\text { rubrigenum }\end{array}$ & CBS $124158=\mathrm{CPC} 15735 \mathrm{ET}$ & $\begin{array}{l}\text { Eucalyptus } \\
\text { camaldulensis }\end{array}$ & Madagascar & NR_152319 & NG_057817 & KJ564338 \\
\hline Vermiconidia antarctica & CBS $136108=$ CCFEE 5489 & rock sample & Antarctica & KF309983 & KF310023 & KF310090 \\
\hline Vermiconidia antarctica & CBS $136107=$ CCFEE 5488ET & rock sample & Antarctica & NR_132888 & KJ564324 & KF310089 \\
\hline Vermiconidia calcicola & CCFEE 5905 & rock sample & Vatican & KP791756 & KR781043 & KT247879 \\
\hline Vermiconidia calcicola & CCFEE 5898 & rock sample & Vatican & KP791757 & KR781044 & KT247880 \\
\hline Vermiconidia calcicola & CCFEE 5714 & rock sample & Italy & KP791760 & KR781047 & KT247883 \\
\hline Vermiconidia calcicola & CBS $140080=$ CCFEE 5770 & rock sample & Italy & NR_145012 & KR781046 & KT247882 \\
\hline Vermiconidia flagrans & CCFEE 5922 & rock sample & Vatican & KP791753 & KR781040 & KT247876 \\
\hline Vermiconidia flagrans & CBS $118283=$ TRN124 & rock sample & Spain & AY559359 & GU323971 & KF310097 \\
\hline Vermiconidia flagrans & CBS $118296=$ TRN114ET & rock sample & Spain & AY559354 & KF310024 & KF310096 \\
\hline Vermiconidia foris & CBS $136106 \mathrm{~T}=$ CCFEE 5459 & rock sample & Italy & KF309981 & GU250390 & KF310088 \\
\hline $\begin{array}{l}\text { Verrucocladosporium } \\
\text { dirinae }\end{array}$ & CBS 112794T & Dirina massiliensis & UK & NR_152317 & EU040244 & - \\
\hline
\end{tabular}


was performed in a touchdown-PCR according to Owczarek-Kościelniak and Sterflinger (2018). LSU PCR reaction was conducted using the following steps: initial denaturation at $95^{\circ} \mathrm{C}$ for $2 \mathrm{~min}, 35$ cycles in the following order $95^{\circ} \mathrm{C}-35 \mathrm{~s}, 56^{\circ} \mathrm{C}-1 \mathrm{~min}$ and $72^{\circ} \mathrm{C}-1 \mathrm{~min}$, and the final elongation in $72^{\circ} \mathrm{C}$ for $10 \mathrm{~min}$. Exo-BAP kit (Eurx, Poland) was used for enzymatic purification of amplicons.

Bidirectional sequencing was performed at Macrogen Europe B.V. (Amsterdam, The Netherlands). Reads were assembled and trimmed in Geneious Prime ${ }^{\circledR}$ 2020.0.4. Generated sequences were deposited at the NCBI's GenBank nucleotide database (Table 1).

BLASTn query was performed in order to verify fungus identity and to find sequences of the closest relatives. Sequences showing high similarity with newly generated sequences, as well as sequences of other related species were downloaded from GenBank and aligned with the MAFFT algorithm (Katoh et al. 2005) as implemented in Geneious Prime ${ }^{\circledR}$ 2020.0.4. In Geneious Prime ${ }^{\circledR}$ 2020.0.4, a dataset of three concatenated loci, ITS, LSU and RPB2, was prepared. Polychaeton citri CBS 116435 was used as an outgroup. The best partitioning model was determined separately for each loci by PartitionFinder 2.1.1 (Lanfear et al. 2016). Analyses were performed for each loci and for the concatenated datablock at the CIPRES Science Gateway (Millet et al. 2010) using maximum likelihood
(ML) analyses using RAxML (Stamatakis 2014) with 1,000 bootstrap replicates and the Bayesian Inference (BI) using MrBayes (Ronquist et al. 2012) in two concurrent runs of four chains for 2,000,000 generations. Final phylogenetic trees were prepared with FigTree 1.4.3. Estimates of the average evolutionary divergence over sequence pairs within groups were calculated in MEGA X (Kumar et al. 2018).

\section{Results and discussion}

The MEA cultures of Extremus adstrictus W3 strain from Kraków were mostly consistent with the original type strain description (Fig. 2). Colonies on MEA grew slowly, reaching up to $12.5 \mathrm{~mm}$ in diameter after 2 months of growth. Colonies were oval, compact, black with distinct margins and embedded in the medium, reverse was black. Hyphae were septate, sparsely branched, pale brown to brown, and 1.0-4.5 $\mu \mathrm{m}$ wide. Conidia were intercalary, one-septate, brown, several in chains, rarely single, and $6.0-9.5 \times 2.5-4.5 \mu \mathrm{m}$. Chlamydospores were produced singly and were brown, globoid to ovoid, growing intercalary or apically, one to two, rarely three-celled, and $6.0-11.0 \times 5.0-10.0 \mu \mathrm{m}$. Colony diameter formed by the isolate from Poland was smaller than colony diameter of type strain of E. adstrictus. Furthermore, chlamydospores
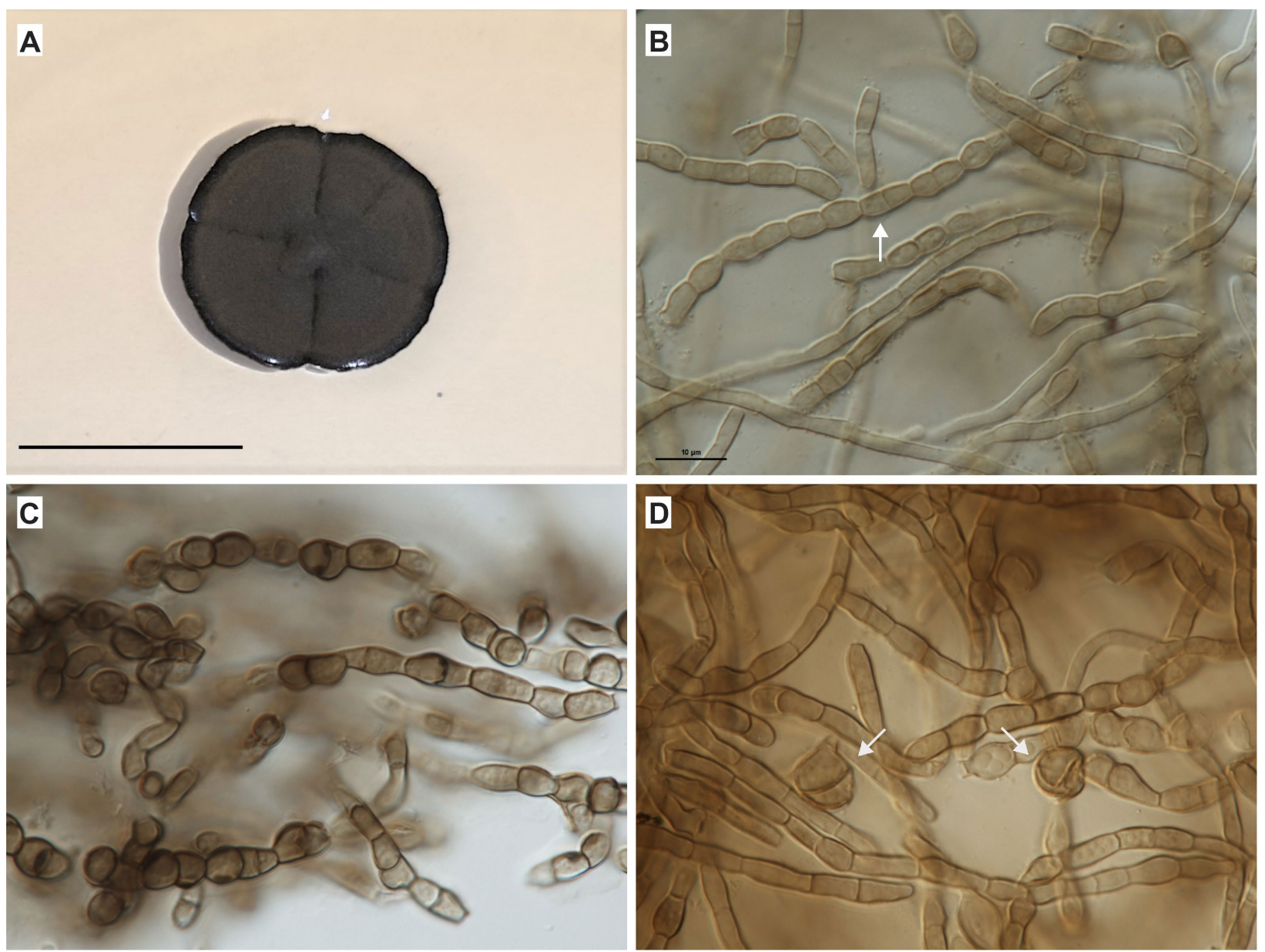

Figure 2. Extremus adstrictus W3 on MEA. A - colony morphology; B - hyphae and conidia in chain (arrow); C - dark-walled hyphae and conidia; $\mathrm{D}-$ hyphae, conidia and two and three-celled chlamydospores (arrows). Scale bars: A $=1 \mathrm{~cm} ; \mathrm{B}-\mathrm{D}=10 \mu \mathrm{m}$. Photographs: A - M. OwczarekKościelniak; B-D - M. Piątek. 


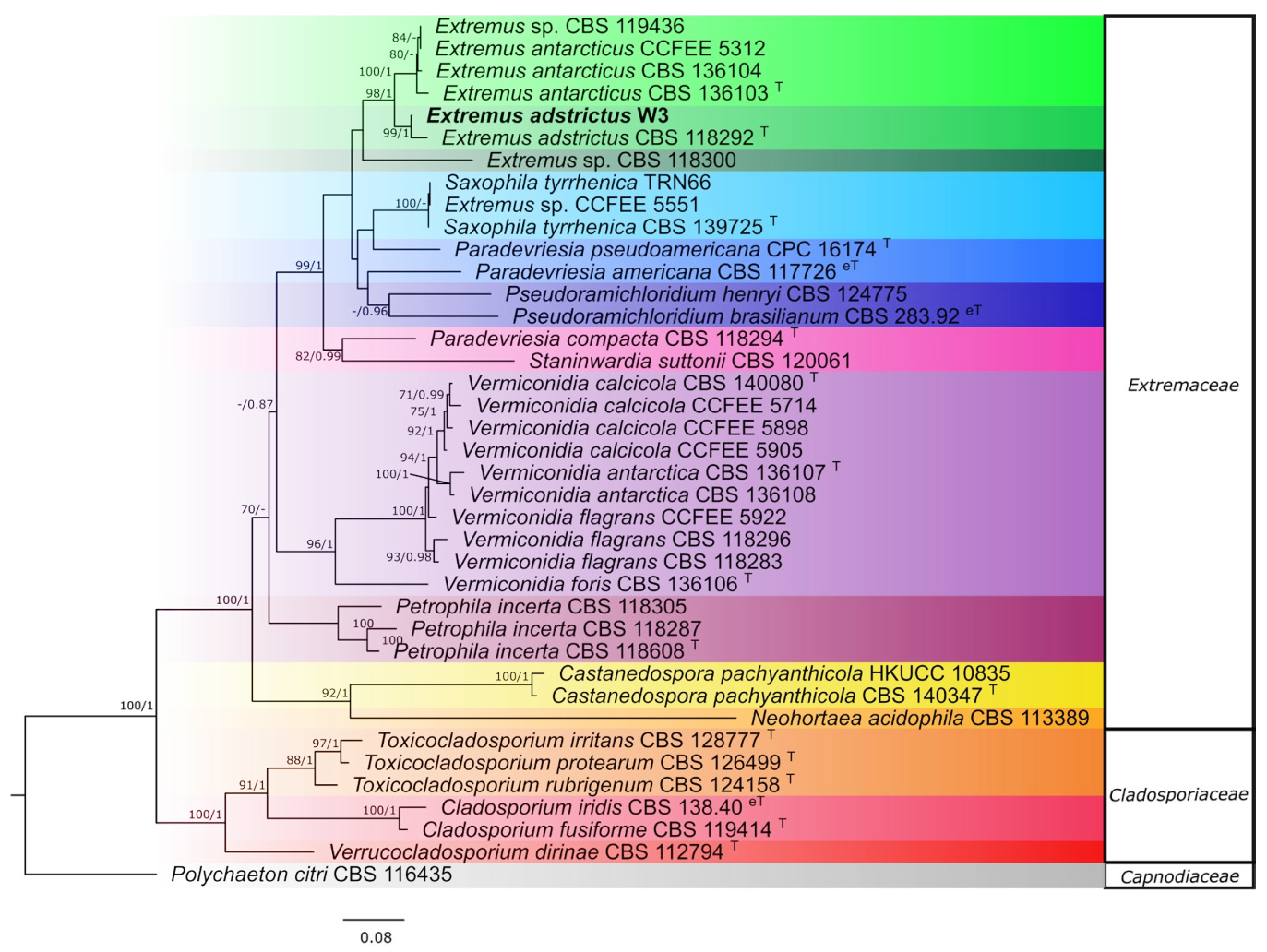

Figure 3. Maximum likelihood consensus tree of a concatenated LSU-ITS-RPB2 loci. Numbers above branches indicate bootstrap support values (ML) and posterior probabilities (BI). The scale bar represents the expected changes per site. Polychaeton citri CBS 116435 was used as an outgroup. $\mathrm{T}$ - type strain; eT - ex-type strain.

were not reported in the original description of the species (Egidi et al. 2014).

Successfully amplified ITS and LSU loci from new Extremus adstrictus W3 strain were 514 bp and 575 bp for ITS and LSU, respectively. BLASTn searches confirmed a close affinity of the analyzed sequences to the sequences of the type strain of E. adstrictus, showing $98.27 \%$ (8 bp difference) and 100\% identity for the ITS and LSU loci, respectively. Overall, 38 ITS sequences from the Extremaceae were downloaded from the GenBank. Extremus adstrictus and E. antarcticus similarity was checked in a distance matrix of the aligned ITS datablock. Type strains of these species were $95.09 \%$ identical. The number of Extremaceae sequences used in phylogenetic tree reconstruction was reduced to 31 by the elimination of the sequences which similarity to the E. adstrictus was lower than 95.09\%. Using Mega $\mathrm{X}$, the average evolutionary divergence over sequence pairs within E. adstrictus group was calculated using the Tajima-Nei model. The rate variation among sites was modeled with a gamma distribution. The divergence within the group was 0.02 , whereas in the Petrophila and Saxophila group it was 0.06 and 0.00 , respectively.

The reconstructed phylogenetic tree of concatenated ITS, LSU and RPB2 datablocks (Fig. 3) confirms affinity of the isolate from Kraków to the genus Extremus and the identification of the Polish strain W3 as E. adstrictus is well supported. Several sequences of uncharacterized cultures and environmental sequences showed affinity to sequences of Extremus adstrictus obtained from type culture and the strain W3 from Kraków that is presented in supplementary files (Fig. S1, Table S1). Considering morphological characteristics of the type strain and isolate W3 from Kraków, it seems probable that most of the unclassified cultures also represent E. adstrictus.

The sequence from culture TRN80 (from limestone) and the sequence from an uncultured Devriesia clone $10 \mathrm{~S} 50 \mathrm{C} 15$ (from soil) form an unsupported clade between Extremus adstrictus and E. antarcticus (Fig. S1). The sequence from the alpine soil, fungal sp. MKOTU91, also has an inconclusive position, visible here as basal to the previous sequences. The specific affinities of these three sequences are unresolved.

Among analyzed sequences related to Extremus adstrictus, only one sequence, from uncultured fungus clone $4248 \_135$ closest to isolate from Kraków, does not originate from the stone material, but from irrigation water from a pond in Lithuania (Marčiulynas et al. 2020). All uncharacterized cultures from the TRN collection originate from limestone material in Spain, TRN433 from the Central Mountain System and the remainder from Mallorca (Ruibal et al. 2005, 2008). Interestingly, all stone isolates of Extremus adstrictus are from substrates rich in calcium from limestone and dolomite in Spain and Poland.

Extremus species are classified as rock-inhabiting fungi. RIF are considered potentially harmful towards inhabited substrate. Not many RIF were reported from a temperate climate of the Central Europe, thus the discovery of E. adstrictus is noteworthy. Among other RIF reported from a temperate climate zone in Europe are Knufia marmoricola, Neocatenulostroma germanicum, Constantinomyces oldenburgensis (Sterflinger \& Piñar 
2001; Owczarek-Kościelniak \& Sterflinger 2018; Ruibal et al. 2018; Owczarek-Kościelniak et al. 2020). More black, slow growing fungi were reported from the Mediterranean area (Marvasi et al. 2012; Edigi et al. 2014; Isola et al. 2015; De Leo et al. 2019).

Although fungi do not raise significant interest, their role in stone biodeterioration is important and undeniable. Recent studies have proven that some RIF species possess corrosive properties (Isola et al. 2013; Breitenbach et al. 2018; Gerrits et al. 2020, 2021), thus awareness of their colonization on man-made structures and objects of cultural heritage needs to be raised and further studies should be conducted.

\section{Acknowledgements}

This study was supported by the statutory funds of the W. Szafer Institute of Botany, Polish Academy of Sciences, Kraków.

\section{Supplementary electronic material}

Figure S1. Maximum likelihood consensus tree of a concatenated ITS-LSU-RPB2 loci of Extremaceae. Numbers above branches indicate bootstrap support values (ML) and posterior probabilities (BI). The scale bar represents the expected changes per site. T - type strain; eT - ex-type strain. Download file

Table S1. Additional fungal ITS sequences used in phylogenetic reconstruction. T - type strain; eT - ex-type strain. Download file

\section{References}

Breitenbach, R., Silbernagl, D., Toepel, J., Sturm, H., Broughton, W. J., Sassaki, G. L. \& Gorbushina, A. A. 2018. Corrosive extracellular polysaccharides of the rock-inhabiting model fungus Knufia petricola. Extremophiles 22: 165-175.

Brewer, T. E. \& Fierer, N. 2017. Tales from the tomb: the microbial ecology of exposed rock surfaces. Environmental Microbiology 20: 958-970.

Cheewangkoon, R., Groenewald, J. Z., Summerell, B. A., Hyde, K. D., To-anun, C. \& Crous, P. W. 2009. Myrtaceae, a cache of fungal biodiversity. Persoonia 23: 55-85.

Crous, P. W., Schumacher, R. K., Akulov, A., Thangavel, R., Hernández-Restrepo, M., Carnegie, A. J., Cheewangkoon, R., Wingfield, M. J., Summerell, B. A., Quaedvlieg, W., Coutinho, T. A., Roux, J., Wood, A. R., Giraldo, A. \& Groenewald, J. Z. 2019. New and Interesting fungi. 2. Fungal Systematics and Evolution 3: 57-134.

Dadachova, E. \& Casadevall, A. 2008. Ionizing radiation: how fungi cope, adapt and exploit with the help of melanin. Current Opinion in Microbiology 11: 525-531.

De Leo, F., Antonelli, F., Pietrini, A. M., Ricci, S. \& Urzì, C. 2019. Study of the euendolithic activity of black meristematic fungi isolated from a marble statue in the Quirinale Palace's Gardens in Rome, Italy. Facies 65: 18

Delgado, G., Miller, A. N. \& Piepenbring, M. 2018. South Florida microfungi: Castanedospora, a new genus to accommodate Sporidesmium pachyanthicola (Capnodiales, Ascomycota). Cryptogamie Mycologie 39: 109-127.

Egidi, E., de Hoog, G. S., Isola, D., Onofri, S., Quaedvlieg, W., de Vries, M., Verkley, G. J. M., Stielow, J. B., Zucconi, L. \& Selbmann, L. 2014. Phylogeny and taxonomy of meristematic rock-inhabiting black fungi in the Dothideomycetes based on multi-locus phylogenies. Fungal Diversity 65: 127-165.

Friedmann, E. I. 1982. Endolithic microorganisms in the Antarctic cold desert. Science 215: 1045-1053.
Gardes, M. \& Bruns, T. D. 1993. ITS primers with enhanced specificity for basidiomycetes - application to the identification of mycorrhizas and rusts. Molecular Ecology 2: 113-118.

Gerrits, R., Pokharel, R., Breitenbach, R., Radnik, J., Feldmann, I., Schuessler, J. A., von Blanckenburg, F., Gorbushina, A. A. \& Schott, J. 2020. How the rock-inhabiting fungus $K$. petricola A95 enhances olivine dissolution through attachment. Geochimica et Cosmochimica Acta Volume 282: 76-97.

Gerrits, R., Wirth, R., Schreiber, A., Feldmann, I., Knabe, N,. Schott, J., Benning, L. G. \& Gorbushina A. A. 2021. High-resolution imaging of fungal biofilm-induced olivine weathering. Chemical Geology 559: 119902. [Available online 24 September 2020]

Gerrits van den Ende, A. H. G. \& de Hoog, G. S. 1999. Variability and molecular diagnostics of the neurotropic species Cladophialophora bantiana. Studies in Mycology 43: 151-162.

Gorbushina, A. A. \& Krumbein, W. E. 2000. Subaerial microbial mats and their effects on soil and rock. In: Riding, R. \& Awramik, S. (eds), Microbial sediments, pp. 161-170. Springer, Berlin.

Grøntoft, T. 2017. Conservation-restoration costs for limestone façades due to air pollution in Krakow, Poland, meeting European target values and expected climate change. Sustainable Cities and Society 29: $169-177$.

Hölker, U., Bend, J., Pracht, R., Tetsch, L., Müller, T., Höfer, M. $\&$ de Hoog, G. S. (2004). Hortaea acidophila, a new acid-tolerant black yeast from lignite. Antonie van Leeuwenhoek 86: 287-294.

Hongsanan, S., Hyde, K. D., Phookamsak, R., Wanasinghe, D. N., McKenzie, E. H. C., Sarma, V. V., Boonmee, S., Lücking, R., Bhat, D. J., Liu, N. G., Tennakoon, D. S., Pem, D., Karunarathna, A., Jiang, S. H., Jones, E. B. G., Phillips, A. J. L., Manawasinghe, I. S., Tibpromma, S., Jayasiri, S. C., Sandamali, D. S., Jayawardena, R.S,. Wijayawardene, N. N., Ekanayaka, A. H., Jeewon, R., Lu, Y. Z., Dissanayake, A. J., Zeng, X. Y., Luo, Z. L., Tian, Q., Phukhamsakda, C., Thambugala, K. M., Dai, D. Q., Chethana, K. W. T., Samarakoon, M. C., Ertz, D., Bao, D. F., Doilom, M., Liu, J. K., PérezOrtega, S., Suija, A., Senwanna, C., Wijesinghe, S. N., Konta, S., Niranjan, M., Zhang, S. N., Ariyawansa, H. A., Jiang, H. B., Zhang, J. F., Norphanphoun, C., de Silva, N. I., Thiyagaraja, V., Zhang, H., Bezerra, J. D. P., Miranda-González, R., Aptroot, A., Kashiwadani, H., Harishchandra, D., Sérusiaux, E., Aluthmuhandiram, J. V. S., Abeywickrama, P. D., Devadatha, B., Wu, H. X., Moon, K. H., Gueidan, C., Schumm, F., Bundhun, D., Mapook, A., Monkai, J., Chomnunti, P., Suetrong, S., Chaiwan, N., Dayarathne, M. C., Yang, J., Rathnayaka, A. R., Bhunjun, C. S., Xu, J. C., Zheng, J. S., Liu, G., Feng, Y. \& Xie, N. 2020. Refined families of Dothideomycetes: Dothideomycetidae and Pleosporomycetidae. Mycosphaere 11: 1553-2107.

Isola, D., Selbmann, L., de Hoog, G. S., Fenice, M., Onofri, S., Prenafeta-Boldu, F. X. \& Zucconi, L. 2013. Isolation and screening of black fungi as degraders of volatile aromatic hydrocarbons. $M y$ copathologia 175: 369-379.

Isola, D., Zucconi, L., Onofri, S., Caneva, G., de Hoog, G. S. \& Selbmann, L. 2016. Extremotolerant rock inhabiting black fungi from Italian monumental sites. Fungal Diversity 76: 75-96.

Jiang, Y. L., Wu, Y. M., Yang, B., Xu, J. J., Zhang, Z. G., Kong, J. H. \& Zhang, T. Y. 2017. Cladosporium, Phialophora, Pseudoramichloridium \& Ticogloea spp. nov. from China. Mycotaxon 132: 677-684.

Katoh, K., Kuma, K., Toh, H. \& Miyata, T. 2005. MAFFT version 5: improvement in accuracy of multiple sequence alignment. Nucleic Acids Research 33: 511-518.

Kumar, S., Stecher, G., Li, M., Knyaz, C. \& Tamura, K. 2018. MEGA $\mathrm{X}$ : Molecular Evolutionary Genetics Analysis across computing platforms. Molecular Biology and Evolution 35: 1547-1549.

Lanfear, R., Frandsen, P. B., Wright, A. M., Senfeld, T. \& Calcott, B. 2016. PartitionFinder 2: New methods for selecting partitioned models of evolution for molecular and morphological phylogenetic analyses. Molecular Biology and Evolution 34: 772-773. 
Marčiulynas, A., Marčiulynienè, D., Lynikienė, J., Gedminas, G., Vaičiukynè, M. \& Menkis, A. 2020. Fungi and Oomycetes in the Irrigation Water of Forest Nurseries. Forests 11: 459.

Marvasi, M., Donnarumma, F., Frandi, A., Mastromei, G., Sterflinger, K., Tiano, P. \& Perito, B. 2012. Black microcolonial fungi as deteriogens of two famous marble statues in Florence, Italy. International Biodeterioration and Biodegradation 68: 36-44.

Miller, M. A., Pfeiffer, W. \& Schwartz, T. 2010. Creating the CIPRES Science Gateway for inference of large phylogenetic trees. In: Proceedings of the Gateway Computing Environments Workshop (GCE), pp. 1-8, New Orleans, LA.

O'Donnell, K. 1993. Fusarium and its near relatives. In: Reynolds, D. R. \& Taylor, J. W. (eds), The fungal holomorph: mitotic, meiotic and pleomorphic speciation in fungal systematics, pp. 225-233. Wallingford, CAB International.

Onofri, S., de la Torre, R., de Vera, J. P., Ott, S., Zucconi, L., Selbmann, L., Scalzi, G., Venkateswaran, K. J., Rabbow, E., Sánchez Iñigo, F. J. \& Horneck, G. 2012. Survival of rock-colonizing organisms after 1.5 years in outer space. Astrobiology 12: 508-516.

Onofri, S., Zucconi, L., Isola, D. \& Selbmann, L. 2014. Rock-inhabiting fungi and their role in deterioration of stone monuments in the Mediterranean area. Plant Biosystems 148: 384-391.

Owczarek-Kościelniak, M. \& Sterflinger, K. 2018. First records of Knufia marmoricola from limestone outcrops in the Wyżyna Krakowsko-Częstochowska Upland, Poland. Phytotaxa 357: 94-106.

Owczarek-Kościelniak, M., Krzewicka, B., Piątek, J., Kołodziejczyk, Ł. M. \& Kapusta, P. 2020. Is there link between the biological colonization of the gravestone and its deterioration? International Biodeterioration \& Biodegradation 148: 104879.

Quaedvlieg, W., Binder, M., Groenewald, J. Z., Summerell, B. A., Carnegie, A. J., Burgess, T. I. \& Crous, P. W. 2014. Introducing the Consolidated Species Concept to resolve species in the Teratosphaeriaceae. Persoonia 33: 1-40.

Ronquist, F., Teslenko, M., van der Mark, P., Ayres, D. L., Darling, A., Höhna, S., Larget, B., Liu, L., Suchard, M. A. \& Huelsenbeck, J. P. 2012. MrBayes 3.2: efficient Bayesian phylogenetic inference and model choice across a large model space. Systematic Biology 61(3): 539-542.

Ruibal, C., Platas, G. \& Bills, G. F. 2005. Isolation and characterization of melanized fungi from limestone formations in Mallorca. Mycological Progress 4: 23-38.

Ruibal, C., Platas, G. \& Bills, G. F. 2008. High diversity and morphological convergence among melanised fungi from rock formations in the Central Mountain System of Spain. Persoonia 21: 93-110.

Ruibal, C., Selbmann, L., Avci, S., Martin-Sanchez, P. M. \& Gorbushina, A. A. 2018. Roof-Inhabiting Cousins of Rock-Inhabiting Fungi: Novel Melanized Microcolonial Fungal Species from Photocatalytically Reactive Subaerial Surfaces. Life 8: 30

Selbmann, L., de Hoog, G. S., Mazzaglia, A., Friedmann, E. I. \& Onofri, S. 2005. Fungi at the edge of life: cryptoendolithic black fungi from Antarctic desert. Studies in Mycology 51: 1-32.

Selbmann, L., de Hoog, G. S., Gerrits van den Ende, A. H. G., Ruibal, C., de Leo, F., Zucconi, L., Isola, D., Ruisi, S. \& Onofri, S. 2008. Drought meets acid: three new genera in a dothidealean clade of extremotolerant fungi. Studies in Mycology 61: 1-20.

Selbmann, L., Isola, D., Egidi, E., Zucconi, L., Gueidan, C., de Hoog, G. \& Onofri, S. 2014. Mountain tips as reservoirs for new rock-fungal entities: Saxomyces gen. nov. and four new species from the Alps. Fungal Diversity 65: 167-182.

Sert, H. B., Sümbül, H. \& Sterflinger, K. 2007. Microcolonial fungi from antique marbles in Perge/Side/Termessos (Antalya/Turkey). Antonie van Leeuwenhoek 91: 217-227.

Staley, J. T., Palmer, F. \& Adams, B. 1982. Microcolonial fungi: common inhabitants on desert rocks? Science 215: 1093-1095.

Stamatakis, A. 2014. RAxML version 8: a tool for phylogenetic analysis and post-analysis of large phylogenies. Bioinformatics 30: 1312-1313.
Sterflinger, K. \& Krumbein, W. E. 1995. Multiple stress factors affecting growth of rock inhabiting black fungi. Botanica Acta 108: 467-538.

Sterflinger, K. \& Prillinger, H. 2001. Molecular taxonomy and biodiversity of rock fungal communities in an urban environment (Vienna, Austria). Antonie van Leeuwenhoek 80: 275-286.

Su, L., Guo, L., Xiang, M., Cai, L. \& Liu, X. 2015. Rupestriomyces and Spissiomyces, two new genera of rock-inhabiting fungi from China. Mycologia 107: 831-844

Summerell, B. A., Groenewald, J. Z., Carnegie, A. J., Summerbell, R. C. \& Crous, P. W. 2006. Eucalyptus microfungi known from culture. 2. Alysidiella, Fusculina and Phlogicylindrium genera nova, with notes on some other poorly known taxa. Fungal Diversity 23: $323-350$

Sutton B. C. 1971. Staninwardia gen.nov. (Melanconiales) on Eucalyptus. Transactions of the British Mycological Society 57: 539-542.

Sun, W., Su, L., Yang, S., Sun, J., Liu, B., Fu, R., Wu, B., Liu, X., Cai, L., Guo, L. \& Xiang, M. 2020. Unveiling the Hidden Diversity of Rock-Inhabiting Fungi: Chaetothyriales from China. Journal of Fungi 6: 187.

Tesei, D., Marzban, G., Zakharova, K., Isola, D., Selbmann, L. \& Sterflinger, K. 2012. Alteration of protein patterns in black rock inhabiting fungi as a response to different temperatures. Fungal Biology 116: 932-940

White, T. J., Bruns, T. D., Lee, S. \& Taylor, J. 1990. Amplification and direct sequencing of fungal ribosomal RNA genes for phylogenetics. In: Innis, M. A., Gelfand, D. H. (eds). PCR Protocols: A Guide to Methods and Applications, pp. 315-322. Academic Press: London.

Wijayawardene, N. N., Hyde, K. D., Lumbsch, H. T., Liu, J. K., Maharachchikumbura, S. S. N., Ekanayaka, A. H., Tian, Q. \& Phookamsak, R. 2018. Outline of Ascomycota: 2017. Fungal Diversity 88: $167-263$.

Wijayawardene, N. N., Hyde, K. D., Al-Ani, L. K. T., Tedersoo, L., Haelewaters, D., Rajeshkumar, K. C., Zhao, R. L., Aptroot, A., Leontyev, D. V., Saxena, R. K., Tokarev, Y. S., Dai, D. Q., Letcher, P. M., Stephenson, S. L., Ertz, D., Lumbsch, H. T., Kukwa, M., Issi, I. V., Madrid, H., Phillips, A. J. L., Selbmann, L., Pfliegler, W. P., Horváth, E., Bensch, K., Kirk, P. M., Kolaříková, K., Raja, H. A., Radek, R., Papp, V., Dima, B., Ma, J., Malosso, E., Takamatsu, S., Rambold, G., Gannibal, P. B., Triebel, D., Gautam, A. K., Avasthi, S., Suetrong, S., Timdal, E., Fryar, S. C., Delgado, G., Réblová, M., Doilom, M., Dolatabadi, S., Pawłowska, J. Z., Humber, R. A., Kodsueb, R., Sánchez-Castro, I., Goto, B. T., Silva, D. K. A., de Souza, F. A., Oehl, F., da Silva, G. A., Silva, I. R., Błaszkowski, J., Jobim, K., Maia, L. C., Barbosa, F. R., Fiuza, P. O., Divakar, P. K., Shenoy, B. D., Castañeda-Ruiz, R. F., Somrithipol, S., Lateef, A. A., Karunarathna, S. C., Tibpromma, S., Mortimer, P. E., Wanasinghe, D. N., Phookamsak, R., Xu, J., Wang, Y., Tian, F., Alvarado, P., Li, D. W., Kušan, I., Matočec, N., Mešić, A., Tkalčec, Z., Maharachchikumbura, S. S. N., Papizadeh, M., Heredia, G., Wartchow, F., Bakhshi, M., Boehm, E., Youssef, N., Hustad, V. P., Lawrey, J. D., Santiago, A. L. C. M. A., Bezerra, J. D. P., Souza-Motta, C. M., Firmino, A. L., Tian, Q., Houbraken, J., Hongsanan, S., Tanaka, K., Dissanayake, A. J., Monteiro, J. S., Grossart, H. P., Suija, A., Weerakoon, G., Etayo, J., Tsurykau, A., Vázquez, V., Mungai, P., Damm, U., Li, Q. R., Zhang, H., Boonmee, S., Lu, Y. Z., Becerra, A. G., Kendrick, B., Brearley, F. Q., Motiejūnaite, J., Sharma, B., Khare, R., Gaikwad, S., Wijesundara, D. S. A., Tang, L. Z., He, M. Q., Flakus, A., Rodriguez-Flakus, P., Zhurbenko, M. P., McKenzie, E. H. C., Stadler, M., Bhat, D. J., Liu, J. K., Raza, M., Jeewon, R., Nassonova, E. S., Prieto,M., Jayalal, R. G. U., Erdoğdu, M., Yurkov, A., Schnittler, M., Shchepin, O. N., Novozhilov, Y. K., Silva-Filho, A. G. S., Gentekaki, E., Liu, P., Cavender, J. C., Kang, Y., Mohammad, S., Zhang, L. F., Xu, R. F., Li YM., Dayarathne, M. C., Ekanayaka, A. H., Wen, T. C., Deng, C. Y., Pereira, O. L., Navathe, S., Hawksworth, D. L., Fan XL., Dissanayake, L. S., Kuhnert, E., Grossart, H. P. \& Thines, M. 2020. Outline of Fungi and fungus-like taxa. Mycosphaere 11: 1060-1456.

Zakharova, K., Tesei, D., Marzban, G., Dijksterhuis, J., Wyatt, T. \& Sterflinger, K. 2013. Microcolonial fungi on rocks: A life in constant drought? Mycopathologia 175: 537-547. 